\title{
TIPOLOGI PRONOMINA PERSONA DALAM BAHASA JAWA, SUNDA DAN MADURA
}

The Typology of Personal Pronouns in Javanese, Sundanese, and Madurese

\author{
Menik Winiharti \\ Bina Nusantara University \\ Jalan Kemanggisan Ilir III No. 45, Palmerah, Jakarta Barat, Indonesia \\ menik_w@binus.ac.id
}

Naskah Diterima Tanggal 23 Juni 2019—Direvisi Akhir Tanggal 26 April 2021—Disetujui Tanggal 1 Desember 2021 doi: https://doi.org/10.26499/rnh/v9i2.1490

\begin{abstract}
Abstrak
Salah satu tipologi bahasa yang terdapat di semua bahasa di dunia adalah pronomina persona. Kajian ini bertujuan untuk mengetahui karakteristik tipologi pronomina persona dalam tiga bahasa daerah di Indonesia, yaitu bahasa Jawa, bahasa Sunda dan bahasa Madura, juga untuk mengetahui persamaan dan perbedaan karakteristik pronomina persona ketiga bahasa itu. Teori atau klaim yang digunakan sebagai rujukan utama adalah dari Moravcsik (2013). Data pronomina persona dalam ketiga bahasa tersebut berupa data sekunder yang diperoleh dari buku teks dan hasil studi terdahulu. Data ini kemudian diidentifikasi terkait masing-masing bentuknya, apakah independen atau tidak. Jika pronomina tersebut bukanlah bentuk yang independen, proses derivasinya dianalisis dan dirumuskan. Hasil studi menunjukkan bahwa bahasa Jawa, Sunda dan Madura memiliki bentuk pronomina persona baik yang independen maupun yang dibentuk melalui proses derivasi. Pronomina persona pertama cenderung memiliki bentuk yang independen sedangkan persona kedua, ketiga dan plural cenderung mengalami proses derivasi. Perbedaan yang jelas terlihat adalah pada pronomina persona tunggal bahasa Jawa yang tidak memiliki bentuk derivasi sama sekali pada tiga tingkatan tuturan.
\end{abstract}

Kata-kata Kunci: tipologi, pronomina persona, independen, derivasi, bahasa Jawa, bahasa Sunda, bahasa Madura

\begin{abstract}
One of the language typologies which can be observed in languages across the globe is personal pronouns. This paper aims to discover the characteristics of personal pronoun typology in three Indonesian local languages, namely Javanese, Sundanese and Madurese. It is also to find the similarities and differences of the three languages' personal pronoun characteristics. The theory or claim used as the main reference is of Moravcsik (2013). The data are secondary ones which are personal pronouns in the three languages collected from textbooks and results of previous studies. The data is then identified with regard to each form, whether it is independent or not. If the pronoun is not independently formed, the process of its derivation is analyzed. The results of the study show that Javanese, Sundanese and Madurese have personal pronouns which are formed both independently and through a derivation process. The first personal pronouns tend to have an independent form while the second, third and plural personal pronouns tend to be formed through a derivation process. The most obvious difference is of the Javanese singular personal pronouns which do not have derivation in three speech levels.
\end{abstract}

Keywords: typology, personal pronoun, independent, derivation, Javanese, Sundanese, Madurese

How to Cite: Winiharti, Menik. (2021). Tipologi Pronomina Persona dalam Bahasa Jawa, Sunda dan Madura. Ranah: Jurnal Kajian Bahasa, 10(2), 252-260. doi: https://doi.org/10.26499/rnh/v9i2.1490 


\section{PENDAHULUAN}

Bahasa Jawa, Sunda, dan Madura merupakan tiga bahasa yang kesemuanya memiliki penutur di pulau Jawa. Menurut Clark (2009) bahasa Jawa, bahasa Sunda dan bahasa Madura merupakan bahasa-bahasa yang saling berkaitan karena merupakan bahasa-bahasa yang termasuk dalam rumpun bahasa Austronesia, khususnya cabang rumpun Western MalayoPolynesian (Oakes, 2009; Tadmor, 2009). Selain itu karena wilayah penuturnya berdekatan (mencakup pulau Jawa dan Madura), ketiga bahasa ini seharusnya dan sewajarnya memiliki karakter tipologi yang sama. Namun demikian dari observasi yang telah dilakukan, tampaknya tiga bahasa itu merupakan bahasa yang berbeda, dalam arti bahwa penulis sebagai orang Jawa tidak memahami bahasa Sunda, terlebih bahasa Madura. Salah satu kategori yang menarik diteliti adalah pronomina persona karena ketiga bahasa ini memiliki tingkat tuturan (speech level) dengan 3 tingkatan utama yang berbeda yaitu rendah, menengah, dan tinggi (kasar, menengah, halus) (Davies, 2010; Djajasudarma dkk., 1994; Oakes, 2009; Sofyan, 2007). Perbedaan ini timbul karena warisan sejarah di pulau Jawa yang pernah dikuasai oleh beberapa kerajaan (Oakes, 2009).

Dalam ilmu tipologi bahasa Pronomina persona merupakan satu pembahasan yang cukup umum dimiliki bahasa-bahasa di dunia (Moravcsik, 2013; Velupillai, 2012). Dalam kaitannya dengan tingkat tuturan, perbedaan pada aspek ini pun berlaku untuk pronomina persona. Moravcsik mengatakan bahwa "pronomina persona juga dapat dibedakan karena faktor-faktor sosial, yaitu tingkatan dan jenis-jenis hubungan antara penutur dengan orang lain." (2013, hlm. 42). Ini tampak berlaku pada penggunaan pronomina dalam bahasa Jepang yang menunjukkan perbedaan gender, yaitu antara penyapa dan pesapa atau penutur dan mitra tutur antara laki-laki dan wanita maupun netral (Syahrial, 2019). Di lain pihak, Gapur, Setia dan Pujiono (2019) menyampaikan bahwa terdapat pronomina persona orang pertama, kedua dan ketiga dalam budaya Jepang yang berkonotasi kasar (disfemia). Terlepas dari penggunaannya, bentuk pronomina persona dalam bahasa Jepang juga menunjukkan bentuk independen dan derivasi. Ini terlihat dari pronomina persona kedua tunggal omae yang berarti 'kamu' dan omaera adalah bentuk pluralnya yang berarti 'kalian.' Ini merupakan pronomina persona yang umumnya dipakai pria dalam percakapan tidak formal sebagai penanda identitas ragam bahasa (Gapur dkk., 2019).

Mardiana (2020) mengupas pronomina persona dalam bahasa Jawa dengan membandingkan penggunaanya di daerah yang berbeda, yaitu di perbatasan Kabupaten Malang dan Blitar. Di dua daerah ini terdapat tiga jenis pronomina, yaitu pronomina persona pertama, pronomina persona kedua, dan pronomina persona ketiga. Kata awakdewe digunakan untuk kata ganti orang pertama yang berpadanan dengan 'kita' dalam bahasa Indonesia. Kata awakmu, koen, kowe, dan sampean merupakan kata ganti orang kedua yang setara dengan kata 'kamu' dalam bahasa Indonesia. Kata dekne, dek'e, dan bocahe dipakai sebagai kata ganti orang ketiga yang setara dengan kata 'dia'. Dia juga menemukan bahwa masyarakat di wilayah Kabupaten Blitar menggunakan penyebutan kata ganti yang cenderung lebih halus (kowe, bocahe, dan sampean) dibanding penyebutan orang Malang (koen). Studi yang juga membahas pronomina bahasa Jawa adalah Suharti dkk. (2017) dengan fokus bahasan dialek Solo. Dalam dialek Solo ini pun pronomina persona dibagi atas pronomina persona pertama, pronomina persona kedua, dan pronomina persona ketiga. Namun Suharti dkk (2017) membahas lebih detil dengan memasukkan perbedaan bentuk tunggal dan jamak. Aku dan kulo adalah contoh pronomina persona pertama tunggal sedangkan dheweke digunakan sebagai bentuk jamaknya. Kemudian kowe, sampeyan, dan panjenengan merupakan pronomina persona kedua tunggal dengan bentuk jamaknya adalah kowe kabeh dan panjenengan sedoyo. Terakhir adalah pronomina persona ketiga tunggal yaitu dhe'e dan mendiang. Bentuk jamak dari pronomina persona ketiga adalah wong iku dan tiang niku (Suharti dkk., 2017). Terkait dengan speech level, Hildayani 
(2019) menyatakan bahwa baik bahasa Jawa dan Sunda memiliki tingkatan tuturan yang berbeda. Bahasa Jawa dikatakan memiliki tiga tingkatan, yaitu kasar, menengah dan halus, sementara bahasa Sunda memiliki dua tingkatan yaitu kasar dan hormat. Namun Djajasudarma dkk. (1994) menggolongkan tingkatan halus ini ke dalam halus dan sangat halus. Sementara itu terkait bahasa Madura, Miqawati (2019) mengatakan bahwa bahasa Madura digunakan secara luas oleh masyarakat di daerah Bondowoso. Dia meneliti bagaimana mereka menggunakan kata sapaan. Temuannya menunjukkan bahwa terdapat empat istilah sapaan yang digunakan, mulai dari yang kurang sopan sampai yang paling sopan, yaitu be 'na atau be'en, sampeyan/sampiyan, panjenengan, dan ajunan. Untuk menyapa orang lain, siswa menggunakan engkok/sengkok, kaule, dhalem, dan abdina. Penggunaan sapaan ini adalah untuk menghormati orang lain (Miqawati, 2019).

\section{LANDASAN TEORI}

Menurut Velupillai (2012) dan Moravcsik (2013) hampir semua bahasa-bahasa di dunia memiliki pronomina persona yang terbagi ke dalam tiga kategori: Orang pertama, orang kedua, dan orang ketiga. Masing-masing bentuk dari ketiga kelompok ini bisa independen maupun derivasi. Bentuk independen yang dimaksud adalah berupa kata pronomina yang tidak dibentuk dengan melekatkan afiks (Moravcsik, 2013) ataupun infleksi (Cysouw, 2009). Klaim yang diajukan Moravcsik (2013) menyatakan bahwa jika sebuah bahasa memiliki pronomina yang independen, maka bahasa itu memiliki kata yang berbeda untuk 'saya', 'kamu', dan 'lainnya' (\#Gen 11 hlm. 44) Klaimnya yang lain adalah bahwa hampir semua bahasa di dunia memiliki beberapa pronomina plural. (\#Gen $12 \mathrm{hlm}$. 44) Kemudian dalam kaitannya dengan pembentukan kata, Moravcsik (2013) juga menyatakan bahwa di semua bahasa, jika ada hubungan derivasi antara pronomina tunggal dan plural, maka bentuk pluralnya diturunkan dari bentuk tunggal, dan bukan sebaliknya. (\#Gen 16, hlm.44) Di sisi lain Cysouw (2009) menggarisbawahi bahwa ada bahasa yang tidak memiliki pronomina yang independen. Dengan kata lain dapat dikatakan bahwa di dunia ini terdapat bahasa yang hanya memiliki sistem pronomina dengan proses derivasi atau afiksasi.

Dengan latar belakang yang telah dipaparkan di atas beserta studi sebelumnya terkait bahasa Jawa, Sunda dan Madura, kajian ini bertujuan untuk menemukan karakteristik tipologi dari pronomina persona bahasa Jawa, Sunda dan Madura, berikut persamaan dan perbedaannya. Klaim yang akan dijadikan acuan utama adalah dari Moravcsik (2013) yaitu \#Gen 11, \#Gen 12 dan \#Gen 16.

\section{METODE PENELITIAN}

Data untuk penelitian ini berupa pronomina persona dalam bahasa Jawa, Sunda dan Madura yang berfungsi utama sebagai subyek dalam kalimat. Jadi kajian ini tidak mencakup pronomina persona yang berfungsi sebagai obyek maupun kepemilikan. Data penelitian yang utama merupakan data sekunder yang diambil dari buku-buku teks dan artikel ilmiah yang membahas masing-masing bahasa tersebut (Davies, 2010; Djajasudarma dkk., 1994; Oakes, 2009; Sofyan, 2007). Selain itu tambahan data bahasa Sunda diperoleh dari dua informan penutur asli bahasa Sunda yaitu Y dan N, sedangkan tambahan data bahasa Jawa diperoleh dari penulis sendiri yang merupakan penutur asli bahasa Jawa. Kemudian data ini dianalisis berdasarkan penemuan dan generalisasi atau klaim yang dinyatakan oleh Cysouw (2009), Moravcsik (2013), dan Velupillai (2012). Analisis difokuskan pada bagaimana pronomina bahasa Jawa, Sunda dan Madura dibentuk, apakah memiliki bentuk yang independen atau tidak. Terkait hal ini, Heine \& Song (2010) menyampaikan bahwa pronomina persona yang independen memiliki properti sebagai berikut: (a) memiliki prosodinya sendiri, (b) fungsi utama atau satu-satunya adalah untuk mengungkapkan perbedaan dalam deiksis persona, (c) 
tidak memiliki konten semantik yang spesifik, (d) menyerupai frase nomina dalam kemungkinan posisinya tetapi biasanya tidak memiliki keterangan, (e) membentuk kelas tertutup. Sebagai kebalikan dari bentuk independen adalah bentuk derivasi atau infleksi seperti yang disampaikan oleh Moravcsik (2013) dan Cysouw (2009) di mana diindikasikan bahwa bentuk pronomina persona yang tidak independen didapatkan dengan proses afiksasi atau infleksi.

Kalau sebuah pronomina tidak memiliki bentuk yang independen, akan dianalisis bagaimana pronomina tersebut dibangun serta proses derivasi atau afiksasi seperti apa yang membentuknya. Setelah masing-masing bentuk dari tiap bahasa diidentifikasi, maka ketiga pronomina dalam bahasa Jawa, Sunda, dan Madura tersebut dibandingkan untuk kemudian dianalisis letak kesamaan maupun perbedaannya.

\section{PEMBAHASAN}

Bagian pertama menyampaikan hasil telaah keseluruhan yang dibagi menurut tiga bahasa yang dikaji, yaitu bahasa Jawa, bahasa Sunda, dan bahasa Madura. Bagian selanjutnya membahas secara lebih rinci terkait fitur-fitur pembentukan pronomina persona di tiga bahasa tersebut, berikut persamaan dan perbedaannya.

\section{Hasil}

Secara garis besar karakteristik pembentukan pronomina persona bahasa Jawa, Sunda, dan Madura dapat dirangkum dalam tabel $1-3$ berikut. Tabel 1 menunjukkan bentuk pronomina persona bahasa Jawa, tabel 2 pronomina persona bahasa Sunda, dan tabel 3 menunjukkan pronomina persona bahasa Madura.

Tabel 1.

Ringkasan Bentuk Pronomina Persona Bahasa Jawa

\begin{tabular}{cll}
\hline Kategori Persona & Bentuk & Keterangan \\
\hline 1 & Independent & \\
2 & independen/derivasi & Derivasi: krama inggil \\
3 & Derivasi & \\
Plural & Derivasi & \\
\hline
\end{tabular}

Tabel 2.

Ringkasan Bentuk Pronomina Persona Bahasa Sunda

\begin{tabular}{cll}
\hline \multicolumn{2}{c}{ Ringkasan Bentuk Pronomina Persona Bahasa Sunda } \\
\hline Kategori Persona & Bentuk & Keterangan \\
\hline 1 & Independen/derivasi & Derivasi: Sangat halus \\
3 & Independen/derivasi & Derivasi: Sangat halus \\
Plural & Derivasi & \\
\hline
\end{tabular}

Tabel 3.

Ringkasan Bentuk Pronomina Persona Bahasa Madura

\begin{tabular}{cll}
\hline Kategori Persona & Bentuk & Keterangan \\
\hline 1 & Independen/derivasi & Derivasi: sebagian di tingkatan Halus \\
2 & Independen/derivasi & Independen: sebagian kecil di tingkatan halus \\
3 & Derivasi & \\
Plural & Derivasi & \\
\hline
\end{tabular}

\section{Pembahasan}

Pembahasan dikelompokkan ke dalam pronomina persona tiap bahasa yang diteliti, yaitu bahasa Jawa, bahasa Sunda, dan bahasa Madura. Setelah itu ketiganya dibandingkan untuk mencari tahu letak persamaan atau perbedaan bentuknya. 


\section{Bahasa Jawa}

Berdasarkan paparan yang ditunjukkan pada tabel 1, pronomina persona bahasa Jawa memiliki bentuk independen untuk semua persona pertamanya. Bentuk persona kedua juga independen kecuali dalam tingkatan krama inggil yang merupakan bentuk derivasi. Akan tetapi proses derivasi ini tidak diturunkan dari persona pertama maupun persona kedua di tingkat tutur yang lebih rendah. Sedangkan untuk persona ketiga dan bentuk plural, semuanya merupakan bentuk derivasi. Sebagai tambahan, secara umum kata kabeh atau sedaya yang berarti 'semua' ditambahkan pada bentuk tunggalnya untuk membentuk persona plural.

Menurut Oakes (2009) bahasa Jawa memiliki satu karakteristik penting dalam hal kesantunan tuturan yang dinyatakan dalam tingkat tuturan (speech level) yang berbeda tergantung dari status sosial penutur dan mitra tuturnya. Sistem ini muncul di abad 16 karena adanya sistem kerajaan yang diwariskan dari tradisi Hindu kuno. Ada tiga tingkatan utama, yaitu krama, madya, ngoko - tinggi, menengah, rendah - di mana krama dan ngoko paling banyak digunakan. Tingkatan ngoko umumnya dipakai antara teman atau yang memiliki status setara. Selain itu, ngoko juga dipakai oleh orang yang memiliki status sosial lebih tinggi untuk berbicara (menunjuk) kepada orang yang statusnya lebih rendah secara sosial. Tingkatan madya pada dasarnya merupakan tingkatan krama dengan kata-kata tertentu yang disingkat dan dengan afiks model ngoko. Tingkatan ini biasanya digunakan oleh dua orang yang tidak saling mengenal. Sedangkan tingkatan krama ada 2, krama dan krama inggil. (inggil = tinggi). Tingkatan krama ini dapat digunakan untuk merujuk kepada orang yang dihargai (honorific), dan orang yang dihormati (deferential) atau memiliki status sosial lebih tinggi.

Dalam hal pronomina persona, pengelompokannya pun mengikuti aturan tingkat tuturan seperti tersebut, yang dapat dilihat pada tabel berikut:

Tabel 4.

Pronomina Persona Bahasa Jawa

\begin{tabular}{lllll} 
& \multicolumn{4}{c}{ Pronomina Persona Bahasa Jawa } \\
\hline Kategori tunggal & Ngoko & Madya & Krama & Krama Inggil \\
\hline Orang pertama & Aku & ---- & Kula & Dalem \\
Orang kedua & Kowe & Samang & Sampeyan & Penjenengan \\
Orang ketiga & Dhewekke & ---- & Piyambakipun & Panjenengané, \\
& & & & Panjenenganipun \\
\hline
\end{tabular}

Diadaptasi dari Oakes (2009, hlm.826)

Pronomina persona yang disebutkan pada tabel 4 di atas merupakan pronomina bentuk tunggal. Pada tingkatan ngoko, pronomina untuk orang pertama dan kedua tunggal memiliki bentuk independen yaitu aku dan kowe berturut-turut. Untuk orang ketiga tunggal, dhewekke bukanlah bentuk independen karena dibangun dengan proses derivasi yang mengambil kata dasar dhewe (sendiri) dengan diimbuhi sufiks -ke. Sementara itu, pada tingkatan madya, tidak ada kata khusus untuk orang pertama dan ketiga tunggal. Pronomina untuk orang kedua tunggal yaitu samang sebenarnya berasal dari tingkatan krama sampeyan yang karena faktor pengucapan disingkat dan dipercepat menjadi samang. Seperti halnya di tingkatan ngoko, tingkatan krama juga memiliki pronomina orang pertama dan kedua yang memiliki bentuk independen yaitu kula dan sampeyan berturut-turut. Sedangkan pronomina ketiga dibentuk melalui proses derivasi piyambak + -ipun. Piyambak sebagai kata dasar memiliki padanan 'sendiri' dalam bahasa Indonesia. Pada tingkat krama inggil, hanya pronomina orang pertama tunggal saja yang memiliki bentuk independen yaitu dalem. Untuk orang kedua dan ketiga tunggal, pembentukannya melalui proses derivasi. Panjenegan dibentuk dari kata dasar jeneng (= nama) kemudian diberi afiks $p a(n)-+-a n$. Sebagai pronomina orang ketiga tunggal, panjenenganipun pun dibentuk melalui proses derivasi, yaitu dengan penambahan afiks $p a(n)$ +-ipun. Untuk proses ini ada 2 afiks yang terlibat. 


\section{Bentuk Plural Pronomina Persona Bahasa Jawa}

Pronomina persona bahasa Jawa pada dasarnya tidak memiliki kata khusus untuk menyatakan plural, dalam arti tidak memiliki bentuk tersendiri seperti kami, kita, kalian, atau mereka dalam bahasa Indonesia. Untuk membuat pronomina persona plural, ditambahkan kabeh untuk ngoko dan sedaya untuk krama, yang keduanya bermakna 'semua'. Akan tetapi ada satu bentuk independen 'kita' (diucapkan kito) yang diambil dari bahasa Indonesia 'kita'. Kalau 'kita' dalam bahasa Indonesia asal maknanya adalah eksklusif - yang dibedakan dari 'kami' - maka kito dapatlah eksklusif maupun inklusif, seperti halnya we dalam bahasa Inggris. Meskipun kito sudah bermakna plural, dalam pemakaiannya sering ditambahkan dengan sedaya dengan tujuan untuk menegaskan bahwa yang dirujuk adalah orang banyak.

\section{Bahasa Sunda}

Tabel 2 menunjukkan bahwa pronomina persona bahasa Sunda memiliki bentuk independen dan derivasi. Bentuk independen dimiliki oleh persona pertama dan kedua tunggal pada tingkatan kasar dan halus. Sedangkan tingkatan sangat halusnya mengalami proses derivasi. Tetapi bentukan derivasi ini tidak diturunkan dari persona di tingkat tutur yang lebih rendah. Sedangkan persona ketiga dibentuk dengan mengalami proses derivasi yang diturunkan dari persona kedua. Bentuk plural juga mengalami proses derivasi yang diturunkan dari masingmasing bentuk persona tunggalnya, kecuali bentuk persona pertama yang ditambahkan dengan kata sarerea atau sadayana yang berarti 'semua(nya)'.

Bahasa Sunda juga memiliki tingkat tutur yang berlaku pula dalam pronomina persona. Kajian ini hanya membahas 3 tingkat tutur, seperti tertera dalam tabel berikut:

$$
\text { Tabel } 5 .
$$

Pronomina Persona Tunggal Bahasa Sunda

\begin{tabular}{llll}
\hline Bentuk Tunggal & Kasar & Halus & Sangat Halus \\
\hline Orang pertama & Urang & Abdi & Simkuring \\
Orang kedua & Maneh & Anjeun & Mantenna \\
Orang ketiga & Manehna & Anjeunna & Anjeunna \\
\hline
\end{tabular}

Diringkas dari Djajasudarma, Gunardi, \& Darsa (1994)

Tabel di atas menunjukkan bahwa pronomina persona yang memiliki bentuk independen adalah orang pertama tunggal (urang, abdi) dan orang kedua tunggal (maneh, anjeun) pada tingkat tutur kasar dan halus. Sedangkan pronomina persona di tingkat sangat halus dibentuk dengan proses afiksasi atau derivasi, yaitu persona pertama simkuring dibangun dari sim- + kuring, persona kedua dibentuk dengan manten $+-n a$. Untuk orang ketiga di semua tingkatan dibentuk dengan proses afiksasi yaitu maneh $+-n a$ dan anjeun $+-n a$.

Tabel 6.

Pronomina Persona Plural Bahasa Sunda

\begin{tabular}{llll}
\hline Bentuk plural & Kasar & Halus & Sangat Halus \\
\hline Orang pertama & Urang sarerea & Abdi sadayana & Simkuring sadayana \\
Orang kedua & Maraneh & Aranjeun (anjeun sadayana) & Marantenna \\
Orang ketiga & Maranehna & Aranjeunna & Marantenna \\
\hline
\end{tabular}

Diringkas dari Djajasudarma, Gunardi, \& Darsa (1994)

\section{Bentuk Plural Pronomina Persona Bahasa Sunda}

Bentuk pronomina persona plural dalam bahasa Sunda seperti ditunjukkan dalam tabel 3 tidak ada yang memiliki bentuk yang independen. Di tingkat kasar ditambahkan sarerea (=semua) pada bentuk independen urang, sedangkan untuk persona kedua dan persona ketiga tidak ada penambahan kata tetapi ada proses derivasi. Untuk persona kedua $-r a-$ disisipkan pada pronomina maneh menjadi maraneh. Untuk persona ketiga sufiks - na diimbuhkan pada pronomina maraneh menjadi maranehna. Kemudian pada tingkat halus dan sangat halus, sadayana (=semua) ditambahkan pada bentuk independen persona pertama abdi dan simkuring. Sedangkan persona kedua aranjeun mengalami proses derivasi dengan disisipkannya - ra-pada bentuk independen anjeun. Akan tetapi untuk persona kedua plural ini juga bisa mengambil 
bentuk independen anjeun yang ditambahkan dengan sadayana. Selain itu sufiks -na ditambahkan pada aranjeun untuk persona plural ketiga di tingkat halus. Di tingkat sangat halus marantenna bisa dipakai baik untuk persona kedua dan persona ketiga dengan menyisipkan ra- pada kata mantenna.

\section{Bahasa Madura}

Tabel 3 menunjukkan bahwa bahasa Madura memiliki bentuk yang paling unik dibandingkan bahasa Jawa dan Sunda. Bentuk independen hanya dimiliki oleh pronomina persona pertama di tingkatan kasar dan menengah, sebagian pronomina di tingkatan halus, dan sebagian kecil persona kedua di tingkatan halus. Selain itu, bentuk yang ada mengalami proses derivasi. Untuk persona ketiga proses derivasinya mengambil bentuk dari persona kedua dengan dilekatkan sufiks -na. Bahasa Madura secara khusus tidak memiliki bentuk plural, akan tetapi pronomina persona plural bisa dibentuk dengan proses reduplikasi atau penambahan kata kabbi yang berarti 'semua' pada bentuk tunggalnya.

Tidak berbeda dari bahasa Jawa dan bahasa Sunda, bahasa Madura pun memiliki speech level yang diterapkan pada pronomina persona. Tingkatannya ada 3 yaitu mapas atau ngoko (kasar), tenga'an (menengah) dan alos (halus). (Davies, 2010) Perbedaan tingkat pada pemakaian pronomina persona diterapkan dengan mempertimbangkan status sosial dari pihakpihak yang terlibat dalam ujaran. Berikut adalah pronomina persona orang pertama, kedua dan ketiga tunggal dalam bahasa Madura.

Tabel 7.

Pronomina Persona Tunggal Bahasa Madura

\begin{tabular}{llll}
\hline Bentuk tunggal & Mapas & Tenga'an & Alos \\
\hline Persona pertama & sengko'/ engko'/ aba' & Bula/gula & $\begin{array}{l}\text { Kaula, (ba)dan kaula/dalem/apdina/apdi } \\
\text { dalem/bal-gebbal dalem }\end{array}$ \\
Persona kedua & ba'na/ba'en/ba'eng/kake/sedha & dika & $\begin{array}{l}\text { Sampeyan/panjenengan/padana/ } \\
\text { sampeyan dalem/ajunan dalem/ } \\
\text { ajunan sampeyan/ajunan panjenengan }\end{array}$ \\
& & & \\
Persona ketiga & aba'na/aba'eng/dibi'na/dibi'eng & & \\
\hline
\end{tabular}

Diadaptasi dari Davies (2010)

Menurut Davies (2010) persona pertama, kedua dan ketiga dalam bahasa Madura memiliki bentuknya masing-masing meskipun persona kedua dan ketiga dibentuk dengan proses derivasi. Ini terlihat jelas di tabel 4 bahwa di tingkat mapas, hanya sengko yang merupakan bentuk independen. Sementara bentuk persona kedua dan ketiga dibangun dari kata dasar $a b a$ ' yang bersinonim dengan 'diri' dan dibi' yang bersinonim dengan 'sendiri'. (Davies, 2010) Pada bentuk ini kemudian dilekatkan sufiks - na menjadi ba'na sehingga membentuk pronomina persona kedua yang bersinonim dengan 'dirimu' dan persona ketiga aba'na berpadanan dengan 'dirinya'. Sementara itu Sofyan (2007) menyatakan bahwa bahasa Madura tidak memiliki pronomina persona ketiga tunggal maupun plural. Menurutnya, jika nama atau jabatan orang yang dibicarakan itu diketahui, maka untuk menunjuk ke orang tersebut akan digunakan nama atau jabatannya. Jika nama atau jabatannya tidak diketahui, penyebutannya hanya menggunakan oreng rowa ('orang itu'). Pernyataan Sofyan ini pada dasarnya tidak bertentangan dengan penemuan Davies (2010) karena apa yang dinyatakan Davies mengindikasikan bahwa pronomina persona tunggal ketiga yaitu aba'na dapat diartikan 'dirinya', yang secara makna tidak jauh berbeda dengan makna 'orang itu'.

Selain hal ini, seperti terlihat dalam tabel 4 , beberapa bentuk pronomina persona kedua dan ketiga yang lain hanya merupakan variasi dialek dan ragam bahasa Madura, dengan ba'na (kamu) dan aba'na (dia) menjadi bentuk yang paling standard (Davies, 2010).

Kemudian ada sejumlah pronomina lain yang digunakan pada tingkat tutur menengah dan halus. Di kelompok menengah terlihat bahwa baik persona pertama dan kedua memiliki bentuk yang independen; bula/gula, dan dika. Sementara pada kelompok halus persona pertama kaula 
dan dalem, dan persona kedua sampeyan memiliki bentuk independen. Selain dari ini, bentuk lain yang ada merupakan derivasi seperti penjenengan dan ajunan.

\section{Bentuk Plural Pronomina Persona Bahasa Madura}

Menurut Davies (2010) "bentuk plural dalam bahasa Madura cukup jarang digunakan dan beberapa penuturnya bahkan tidak tahu bagaimana membentuknya. Ini mendukung pendapat dari Sofyan (2007) yang menyatakan bahwa bahasa Madura tidak memiliki bentuk plural untuk semua kategori persona. Tetapi ada satu cara untuk membentuk persona plural, yaitu dengan mengulang (reduplikasi) kata seperti $a b a^{\prime}$ menjadi $b a^{\prime}$-aba'. Proses reduplikasi ini berlaku untuk semua kategori pronomina. Cara yang lain adalah dengan menambahkan kabbi yang berpadanan dengan 'semua' (Davies, 2010). Sehingga bentuk pronomina plural pada bahasa Madura akan seperti ini:

Tabel 8.

Pronomina Persona Plural Bahasa Madura

\begin{tabular}{|c|c|}
\hline Kategori & Plural \\
\hline Kami/kita (persona pertama) & sengko' kabbi \\
\hline Kalian (persona kedua) & ba'na kabbi \\
\hline Mereka (persona ketiga) & aba'na kabbi \\
\hline
\end{tabular}

Dari pembahasan mengenai pronomina persona dari ketiga bahasa di atas, dapat dikatakan bahwa bahasa Jawa, Sunda dan Madura memiliki karakter tipologi yang mirip meskipun masing-masing memiliki bentuk independen dan derivasinya masing-masing. Perbedaan tipologi ketiga bahasa itu pun ada meskipun tidak banyak seperti persamaannya.

\section{PENUTUP}

Pronomina persona merupakan satu bagian penting dalam studi tipologi. Bahasa Jawa, Sunda dan Madura memiliki pronomina persona yang secara garis besar memiliki karakter tipologi yang dapat dikatakan serupa. Pada umumnya ketiga bahasa ini memiliki tingkat tuturan (speech level) rendah, menengah dan tinggi (kasar - menengah - halus) yang membedakan bentuk atau sapaan tergantung dari status sosial orang-orang yang terlibat dalam ujaran. Untuk pronomina personanya, ketiga bahasa ini memiliki bentuk independen dan bentuk derivasi. Bentuk independen cenderung hanya dimiliki oleh pronomina persona pertama dan sebagian kecil persona kedua di tingkat kasar atau menengah. Dengan kata lain, dapat dikatakan bahwa sebagian besar pronomina persona kedua dari ketiga bahasa ini mengalami proses derivasi. Bentuk pronomina persona ketiga dapat dikatakan cenderung merupakan bentuk derivasi. Kemudian untuk pronomina persona plural di ketiga bahasa ini cenderung tidak memiliki bentuk tersendiri, dalam arti bahwa kata 'semua' harus ditambahkan pada masing-masing kategori pronomina untuk memberi makna plural, kecuali beberapa pronomina persona kedua dan ketiga dalam bahasa Sunda yang mengalami proses afiksasi. Kemudian perbedaan yang paling mencolok terlihat di pronomina persona tunggal bahasa Jawa yang tidak memiliki bentuk derivasi sama sekali pada tiga tingkatan tuturan. Perbedaan lainnya adalah bahwa pronomina persona kedua (tingkat krama inggil) dan persona ketiga (semua tingkat tutur) dalam bahasa Jawa mengalami derivasi yang tidak diturunkan dari persona pertama atau kedua, melainkan diturunkan dari kata yang tidak ada dalam dalam daftar pronomina persona. Sedangkan proses derivasi untuk pronomina persona ketiga bahasa Sunda dan Madura dapat dikatakan cenderung diturunkan dari bentuk persona keduanya.

Keseluruhan hasil kajian ini secara garis besar dapat dikatakan tidak bertentangan dengan klaim yang diajukan oleh Moravcsik (2013, \#Gen 11, \#Gen 12, \#Gen 16) dan memperkaya hasil studi sebelumnya yang dilakukan oleh Heine \& Song (2010); Hildayani (2019); Mardiana (2020); Miqawati (2019); Sofyan (2007); dan Suharti dkk. (2017). 


\section{DAFTAR RUJUKAN}

Clark, R. (2009). Austronesian Languages. In B. Comrie (Ed.), The World's Major Languages (2nd ed., pp. 781-790). Routledge.

Cysouw, M. (2009). The Paradigmatic Structure of Person Marking. Oxford University Press.

Davies, W. D. (2010). A Grammar of Madurese. De Gruyter Mouton. https://doi.org/10.1515/9783110224443

Djajasudarma, T. F., Gunardi, G., \& Darsa, U. A. (1994). Tata Bahasa Acuan Bahasa Sunda. Pusat Pembinaan dan Pengembangan Bahasa.

Gapur, A., Setia, E., \& Pujiono, M. (2019). Disfemia Pronomina Persona di antara Karakter Pria dalam Komik Akira No.2 Karya Hiromasa Okushima. Jurnal KATA, 3(2), 287-298.

Heine, B., \& Song, K. (2010). On the genesis of personal pronouns: Some conceptual sources. Language and Cognition, March. https://doi.org/10.1515/langcog.2010.005

Hildayani, D. (2019). Cross-Cultural Communication: Javanese and Sundanese Vocabularies the Same in Form and Different in Meaning. BAHTERA: Jurnal Pendidikan Bahasa dan Sastra, 18(2), 176185. https://doi.org/10.21009/BAHTERA.182.07

Mardiana, D. I. N. A. (2020). Pronomina Persona dalam Bahasa Jawa di Perbatasan Kabupaten Malang dan Kabupaten Blitar. Hasta Wiyata, 3(1), 1-6. https://doi.org/10.14710/nusa.14.3.398-404

Miqawati, A. H. (2019). Language Variation in Lexical Variables of Madurese Terms of Address Used by Youths in Bondowoso Regency: A Sociolinguistic Investigation. Linguistic, English Education and Art (LEEA) Journal, 3(1), 150-158. https://doi.org/10.31539/leea.v3i1.997

Moravcsik, E. A. (2013). Introducing Language Typology. Cambridge University Press. https://doi.org/10.1017/CBO9780511978876

Oakes, M. P. (2009). Javanese. In B. Comrie (Ed.), The World's Major Languages (2nd ed., pp. 819832). Routledge.

Sofyan, A. (2007). Beberapa keunikan linguistik Bahasa Madura. Humaniora, 19(3), 232-240.

Suharti, S., Charlina, C., \& Sinaga, M. (2017). Pronomina of Central Java Language Solo Dialect. Jurnal Online Mahasiswa (JOM) Bidang Keguruan Dan Ilmu Pendidikan, 4(1), 1-11.

Syahrial. (2019). Pronomina Persona Bahasa Jepang Berdasarkan Gender (Kajian Struktur dan Semantik). Jurnal KATA, 3(1), 93-105. https://doi.org/10.22216/kata.v3i1.3980

Tadmor, U. (2009). Malay-Indonesian. In B. Comrie (Ed.), The World's Major Languages (2nd ed., pp. 791-818). Routledge.

Velupillai, V. (2012). An Introduction to Linguistic Typology. John Benjamins B.V. https://doi.org/10.1075/z.176 